\title{
FAKTOR-FAKTOR YANG BERHUBUNGAN DENGAN KEJADIAN STUNTING PADA ANAK USIA 6-24 BULAN
}

\author{
M Rizal Permadi1 ${ }^{*}$, Diffah Hanim² ${ }^{2}$ dan Kusnandar ${ }^{2}$ \\ ${ }^{1}$ Program, Studi, Gizi Klinik, Politeknik Negeri Jember \\ Jln Mastrip Po Box 164,Jember Jawa Timur - Indonesia \\ ${ }^{2}$ Magister, Ilmu Gizi, Universitas, Sebelas, Maret Surakarta \\ Jln Ir. Sutami, No. 36A, Surakarta, Jawa Tengah- Indonesia \\ *Email : rizalpermadi@polije.ac.id
}

\begin{tabular}{l} 
Article Info \\
Article history: \\
Received January $14^{\text {th }}, 2021$ \\
Revised February $21^{\text {th }}, 2021$ \\
Accepte March $25^{\text {th }}, 2021$ \\
\hline
\end{tabular}

Keywords :

Breasfeeding; Economic levvel; Nutrition intake; Parental height

\section{Kata Kunci :}

Air susu ibu; Asupan zat gizi; Pendapatan keluarga stunting; Tinggi badan orang tua

\begin{abstract}
Background : Prevalence, of stunting, under five years in Boyolali Regency was 28\%. Stunting caused by breastfeeding pattern, inadequate intake of energy, carbohydrate, fat, protein, parental height and economic level.

Objectives : This objective of this, research, is to analyze, the correlation of the energy, carbohydrate, fat, protein, parental height and economic level intake to the stunting in Boyolali Regency

Method : This, research, design, used a cross-sectional approach. Subjects aged 6-24 months who were stunting in this study were 33 children, 77 children were not stunted, data was tested chi-square.

Results : The correlation of Breasfeeding pattern, dietary intake of energy, carbohydrates, parental height were significant, correlation with, stunted as indicated, by the p-value <0.05. There was no correlation intake of fat, protein anda economic level with stunted as indicated, by the, $p$-value, $>0.05$
\end{abstract}

Conclusion : Dietary intake of energy, carbohydrate, breastfeeding pattern, and parental height, had correlation with the stunting child.

\footnotetext{
ABSTRAK

Latar Belakang : Prevalensi, stunting, balita di, Kabupaten Boyolali $28 \%$. Stunting disebabkan oleh pola menyusui, kurangnya asupan energi, karbohidrat, lemak, protein, tinggi badan orang tua dan pendapatan keluarga.
}

Tujuan : Penelitian bertujuan untuk, menganalisis, faktor, yang berhubungan dengan stunting anak usia 6-24 bulan di Kabupaten Boyolali.

Metode : Desain penelitian ini menggunakan pendekatan crosssectional. Subjek berusia 6-24 bulan yang stunting pada penelitian ini 33 anak, tidak stunting 77 anak, data diuji chi-square.

Hasil : Hasil, uji statistik, terdapat hubungan, antara pola menyusui $(p=0,000)$, asupan energi, $(p=0,000)$, asupan karbohidrat $(p=0,000)$, tinggi badan ayah $(p=0,000)$, tinggi badan ibu $(p=0,000)$, dengan stunting. Tidak berhubungan antara asupan lemak $(p=0,828)$, asupan protein, $(p=0,615)$, dan pendapatan keluarga $(p=0,668)$ dengan stunting.

Kesimpulan : Asupan karbohidrat, energi, pola menyusui dan, tinggi badan, orang, tua, berhubungan dengan, kejadian, stunting. 


\section{PENDAHULUAN}

Masa emas tumbuh kembang anak pada, usia 0-24 bulan, mengalami, pertumbuhan, yang, pesat. Asupan gizi pada masa itu sangat penting,sehingga perlu, perhatian, khusus. Pada, masa, bayi, asupan gizi yang didapat sangat bergantung, pada, pengasuhnya. Pada tahun pertama, berat lahir bayi naik tiga kali lipat, dan selama periode ini, 65\%, dari total pertumbuhan otak terjadi (Meadow et al., 2005). Stunting dapat mempengaruhi terganggunya metabolisme, fungsi kognitif dan penurunan produktifitas (Branca, 2005).

Di negara berpenghasilan rendah dan menengah, stunting, merupakan ,masalah, kesehatan utama karena dikaitkan dengan peningkatan risiko kematian anak. Keterlambatan perkembangan mempengaruhi fisik dan fungsional tubuh. Anak-anak dengan keterlambatan perkembangan dan pertumbuhan berpotensi menjadi remaja stunting (Black, 2008).

Data, Riskesdas menunjukkan, prevalensi, stunting terus mengalami peningkatan. Dari 35,6\%, ditahun 2010, menjadi 37,2 pada tahun 2013. Stunting meningkat di Jawa Tengah tahun 2010 (35,3\%) dan tahun 2013 (36,2\%) (Kemenkes, 2013). Kabupaten Boyolali balita stunting pada tahun 2015 sebesa 28\% (Dinkes Boyolali, 2015), Batasan stunting <20\%, artinya stunting di Kabupaten Boyolali masi tinggi (WHO, 2005)

Pola menyusui ASI eksklusif mengurangi stunting. Air Susu Ibu makanan paling baik dan memiliki mempunyai zat gizi sesuai untuk anak (Roesli, 2007). Menurut WHO (2013) stunting disebabkan Air Susu Ibu tidak eksklusif dan lamanya pemberian $<2$ tahun, kurangnya asupan dan rendahnya penghasilan keluarga.

Anak usia 6-24 bulan terjadi pertumbuhan dan perkembangan yang sangat cepat sehingga membutuhkan energi yang lebih besar (Sherlin dan Edelstein, 2011). Tubuh manusia memberikan respon terhadap asupan energi tercermin dalam keadan fisiologis (Suhardjo, 2003). Bentuk respon dari anak yang mempertahankan keseimbangan energinya akibat dari kekurangan energi kronis terlihat pada tubuh (Waterlow, 2003). Pertumbuhan anak perlu banyak zat gizi protein. Asam amino yang ada pada protein akan mempengaruhi pertumbuhan organ, jaringan, berat badan, tinggi dan lingkar kepala (Arisman, 2009). Anak dengan asupan protein yang kurang akan tumbuh melambat dibandingkan cukup protein (Bender, 2002). Penelitian yang dilakukan di Cina menunjukkan asupan lemak, protein dan energi berkorelasi dengan stunting untukanak usia < 5 tahun (Xioli et al., 2009). Faktor yang berkorelasi dengan stunting yaitu tingkat ekonmi dan tinggi badan orangtua (Jahari, 2012). Ibu pendek berpeluang memiliki anak stunting karena strutur gen menurun pada anak (Rahayu,2011). Nasikhah et al (2012) menyebutkan pendapatan ekonom rendah berisiko terjadi stutnting. Penelitian ini betujuan menganalisis faktor-faktor yang berkorelasi dengan stunting.

\section{METODE PENELITIAN}

Penelitian potong lintang dilakukan di Puskesmas Andong Boyolali, Klego dan Banyudono bulan Januari sampai Maret 2016, merupakan puskesmas dengan angka stunting yang tinggi. Kelaikan etik penelitian no: 30/I/HREC/2016.

Pada penelitian ini anak kurang dari dua tahun menjadi populasi, sejumlah 100 anak 6-24 bulan menjadi sampel. Sampel dengan kategori anak sehat, berat badan lahir normal, serta wali menandatangani persetujuan penelitian.

Data panjang badan, pola menysuui, asupan energi, karbohidrat, lemak, protein, tinggi badan orang tua dan pendapatan dikumpulkan dengan bantuan kuesioner. Panjang badan diukur menggunakan lenght board. Jumlah asupan dikumpulkan dengan wawancara terhadap ibu atau pengasuh anak baduta menggunakan recall 1x24 jam sebanyak dua kali pada hari yang tidak berurutan dengan bantuan form recall. Tinggi badan orang tua diukur menggunakan microtoice. Anak kemudian dikategorikan stunting bila panjang badan menurut umur <-2SD dan tidak stunting bila panjang badan menurut umur $\geq-2$ SD. Asupan kurang bila $<80 \%$ AKG dan dikategorkan baik bila $\geq 80 \%$ AKG. Tinggi badan ibu dikategorikan pendek bila $<150 \mathrm{~cm}$ dan normal jika tinggi badan $\geq 150 \mathrm{~cm}$ Tinggi badan ayah di kategorikan pendek bila $<160 \mathrm{~cm}$ dan normal bila tinggi badan $\geq 160 \mathrm{~cm}$. Pendapatan keluarga dikategorikan $<U M R$ dan $\geq U M R$. Data diuji dengan chi square.

\section{HASIL DAN PEMBAHASAN PENELITIAN}

Karakteristik responden penelitian berdasarkan kelompok usia, jenis kelamin, status gizi dan asupan, terdapat pada Tabel 1 
Tabel 1. Karateristik Responden Bersarkan Kelompok Usia, Jenis Kelamin, Status Gizi, Dan Asupan

\begin{tabular}{|c|c|c|c|c|}
\hline \multirow{2}{*}{ Karateristik } & \multicolumn{3}{|c|}{ Usia (bulan) } & \multirow{2}{*}{$\begin{array}{c}\text { Total } \\
\mathrm{n}(100)\end{array}$} \\
\hline & $6-11 \mathrm{n}(\%)$ & $12-17$ n (\%) & $18-24$ n (\%) & \\
\hline \multicolumn{5}{|l|}{ Jenis Kelamin } \\
\hline Perempuan & $22(45,8)$ & $17(35,4)$ & $9(18,8)$ & $48(100)$ \\
\hline Laki-laki & $20(38,5)$ & $17(32,7)$ & $15(28,8)$ & $52(100)$ \\
\hline \multicolumn{5}{|l|}{ Status Gizi BB/U } \\
\hline Gizi Buruk & $0(0)$ & $1(33,3)$ & $2(66,7)$ & $3(100)$ \\
\hline Gizi Kurang & $3(20)$ & $7(46,7)$ & $5(33,3)$ & $15(100)$ \\
\hline Gizi Baik & $39(48,1)$ & $25(30,9)$ & $17(21)$ & $81(100)$ \\
\hline Gizi Lebih & $0(0)$ & $1(100)$ & $0(0)$ & $1(100)$ \\
\hline \multicolumn{5}{|l|}{ Status Gizi PB/U } \\
\hline Sangat Pendek & $0(0)$ & $2(40)$ & $3(60)$ & $6(100)$ \\
\hline Pendek & $7(25)$ & $9(32,1)$ & $12(42,9)$ & $28(100)$ \\
\hline Normal & $34(52,3)$ & $22(33,8)$ & $9(13,8)$ & $65(100)$ \\
\hline Tinggi & $1(50)$ & $1(50)$ & $0(0)$ & $2(100)$ \\
\hline \multicolumn{5}{|l|}{ Status Gizi BB/PB } \\
\hline Sangat Kurus & $0(0)$ & $1(100)$ & $0(0)$ & $1(100)$ \\
\hline Kurus & $1(11,1)$ & $5(55,6)$ & $3(33,3)$ & $9(100)$ \\
\hline Normal & $41(46,1)$ & $27(30,3)$ & $21(23,6)$ & $49(100)$ \\
\hline Gemuk & 0 & $1(100)$ & $0(0)$ & $1(100)$ \\
\hline \multicolumn{5}{|l|}{ Asupan Energi } \\
\hline Kurang & $5(13,9)$ & $17(47,2)$ & $14(38,9)$ & $36(100)$ \\
\hline Baik & $37(57,8)$ & $17(26,6)$ & $10(15,6)$ & $64(100)$ \\
\hline \multicolumn{5}{|c|}{ Asupan Karbohidrat } \\
\hline Kurang & $5(94)$ & $30(56,6)$ & $18(34)$ & $53(100)$ \\
\hline Baik & $37(78,7)$ & $4(8,5)$ & $6(12,8)$ & $47(100)$ \\
\hline \multicolumn{5}{|l|}{ Asupan Lemak } \\
\hline Kurang & $15(31,9)$ & $18(38,3)$ & $14(29,8)$ & $47(100)$ \\
\hline Baik & $27(50,9)$ & $16(30,2)$ & $10(18,9)$ & $53(100)$ \\
\hline \multicolumn{5}{|l|}{ Asupan Protein } \\
\hline Kurang & $17(37)$ & $19(41,3)$ & $10(21,7)$ & $46(100)$ \\
\hline Baik & $25(46,3)$ & $15(27,8)$ & $14(25,9)$ & $54(100)$ \\
\hline
\end{tabular}

Hasil penelitian ada hubungan pola menyusui $(\mathrm{p}=0,000)$, asupan energi $(\mathrm{p}=0,000)$, asupan karbohidrat $(\mathrm{p}=$ $0,000)$, tinggi badan ayah $(\mathrm{p}=0,000)$, tinggi badan ibu $(\mathrm{p}=0,000)$ dengan stunting. Namun tidak berhubungan antara asupan lemak $(\mathrm{p}=0,828)$, asupan protein $(\mathrm{p}=0,615)$, dan pendapatan keluarga $(\mathrm{p}=0,668)$. Analisis korelasi antar variabel dapat dilihat pada Tabel 2. 
Tabel 2 Hubungan Pola Menyusui, Asupan Karbohidart, Lemak, Energi, Protein, Tinggi Badan Orang Tua , Dan Pendapatan Keluarga

\begin{tabular}{|c|c|c|c|c|c|}
\hline \multirow{2}{*}{ Variabel } & \multicolumn{2}{|c|}{ Kategori PB/U } & \multirow{2}{*}{ Tota $\mathrm{n}(\%)$} & \multirow{2}{*}{ PR } & \multirow{2}{*}{$\mathrm{P}$ value } \\
\hline & Stunting n (\%) & Tidak Stunting n (\%) & & & \\
\hline \multicolumn{6}{|l|}{ Pola Menyusui } \\
\hline Eksklusif & $5(11,9)$ & $37(88,1)$ & $42(100)$ & - & $0,001 *$ \\
\hline Predominan & $3(60)$ & $2(40)$ & $5(100)$ & & \\
\hline Parsial & $25(47,2)$ & $28(52,8)$ & $53(100)$ & & \\
\hline \multicolumn{6}{|l|}{ Asupan Energi } \\
\hline Kurang & $24(66,7)$ & $12(33,3)$ & $36(100)$ & 12,2 & $0,000^{*}$ \\
\hline Baik & $9(14,1)$ & $55(85,9)$ & $64(100)$ & & \\
\hline \multicolumn{6}{|c|}{ Asupan Karbohidrat } \\
\hline Kurang & $27(50,9)$ & $26(49,1)$ & $53(100)$ & 7,096 & $0,000^{*}$ \\
\hline Baik & $6(12,8)$ & $41(87,2)$ & $47(100)$ & & \\
\hline \multicolumn{6}{|l|}{ Asupan Lemak } \\
\hline Kurang & $15(31,9)$ & $32(68,1)$ & $47(100)$ & 0,911 & 0,828 \\
\hline Baik & $18(34)$ & $35(66)$ & $53(100)$ & & \\
\hline \multicolumn{6}{|l|}{ Asupan Protein } \\
\hline Kurang & $14(30,4)$ & $32(69,6)$ & $46(100)$ & 0,806 & 0,615 \\
\hline Baik & $19(35,2)$ & $35(64,8)$ & $54(100)$ & & \\
\hline \multicolumn{6}{|c|}{ Tinggi Badan Ayah } \\
\hline Pendek & $11(73,3)$ & $4(26,7)$ & $15(100)$ & 7,875 & $0,000 *$ \\
\hline Normal & $22(25,9)$ & $63(74,1)$ & $85(100)$ & & \\
\hline \multicolumn{6}{|l|}{ Tinggi Badan Ibu } \\
\hline Pendek & $15(62,5)$ & $9(37,5)$ & $24(100)$ & 5,37 & $0,000^{*}$ \\
\hline Normal & $18(23,7)$ & $58(76,3)$ & $75(100)$ & & \\
\hline \multicolumn{6}{|c|}{ Pendapatan Keluarga } \\
\hline$<$ UMR & $12(37,5)$ & $20(62,5)$ & $32(100)$ & 1,343 & 0,668 \\
\hline$\geq \mathrm{UMR}$ & $21(30,9)$ & $47(69,1)$ & $68(100)$ & & \\
\hline
\end{tabular}

Ada hubungan antara pola menyusui dan stunting. Sebagian besar stunting masuk dalam kategori mendapatkan ASI predominan dan parsial. Sedangkan anak tidak stunting lebih banyak mendapatkan ASI eksklusif. Menyusui predominan adalah meyusui bayi namun pernah memberikan minuman berbasir air seperti teh. Sedangkan menyusui parsial selain ASI, seperti bubur, susu formula dan makanan lain sebelum usia 6 bulan (Kemenkes, 2010). ASI eksklusif menurut WHO (2013) dapat mencegah terjadinya stunting dan gagal tumbuh. Hal tersebut dapat terjadi karena ASI berdampak pada menurunkan kejadian diare pada anak. Karena ASI memiliki kandungan antibodi IgA (immunoglobin A) dan sitokin anti inflamasi yang memproteksi dari organisme pathogen yang terdapat pada mukosa usus yang menyebabkan inflamasi. ASI menghasilkan protein transforming growth factor beta yang akan menormalkan fungsi usus sehingga membantu penyerapan zat-zat gizi. Kuchenbecker et al $(2015)$ memberikan hasil terdapat korelasi $(p<0,05)$ ASI eksklusif dan peningkatan rata rata tinggi badan pada anak berusia dibawah 24 bulan.

Pada penelitian ini energi berkorelasi denga stunting. Energi terutama dipasok oleh karbohidrat dan lemak,. Asupan gizi sangat dibutuhkan pada anak usia 6- 24 bulan, asupan zat gizi akan menghasilkan energi yang digunakan untuk proses metabolisme dalam tubuh. Tubuh manusia memberikan respon terhadap asupan energi yang tidak mencukupi tercermin dalam keadaan fisiologis (Suhardjo, 2003). Kelebihan energi berakibat obesitas, kekurangan berakibat kurus dan stutning (WHO, 2007). Di Provinsi NTT stuntingterjadi pada anak yang kurang mengonsumsi energi (Hidayah, 2011)

Asupan karbohidrat berkorelasi dengan stunting. Jaringan tubuh memerlukan karbohidrat untuk melindungi protein, metabolism lemak, dan menyerap kalsium (Hutagalung, 2004). Tinggi badan yang kurang berkorelasi pada kuranya konsumsi makanan (Asiss et al, 2004). Zat gizi makronutrien sebagai sumber energi tubuh dan pertumbuhan (International Institute for Population Sciences, 2000).

Asupan lemak tidak berkorelasi dengan stunting. Lemak adalah sumber energi utama yang dibutuhkan anak sampai usia dua tahun untuk pertumbuhan dan aktifitas fisik. Lemak membentuk membran dengan bantuan 
kolesterol serta asam lemak (Koswara, 2006). Penelitian yang dilakukan oleh Chunming (2000) pada 8 provinsi di Cina disimpulkan ada korelasi antara asupan protein, lemak dan stunting pada anak laki-laki yang berusia dibawah 6 tahun.

Asupan protein pada penelitian ini tidak berhubungan dengan stunting. Anak dalam masa pertumbuhan perlu protein yang banyak. Asam amino pada protein akan mempengaruhi pertumbuhan organ, jaringan, berat badan, tinggi dan lingkar kepala (Arisman, 2000). Anak dengan konsumsi protein yang kurang tumbuh lebih lambat dibandingkan anak dengan konsumsi cukup (Bender, 2002). Sejalan dengan penelitian (Ramadhan, 2019),stunting tidak berkorelasi dengan asupan protein anak remaja. Penelitian di Semarang menunjukkan stunting berkorlasi dengan asupan protein pada anak usia $<5$ tahun (Sundari, 2016).

Pada peneltiian ini tinggi badan orang tua berkorelasi dengan stunting. Kedua orang tua dengan postur tubuh pendek yang diseabkan defisiensi hormone pertumbuhan maka anaknya berpeluang akan mewarisi kromosom yang mengandung gen pembawa sifat pendek (Nasikhah, 2012). Tinggi badan ibu salah satu faktor risiko stunting pada anak usia $<24$ bulan. Ibu yang pendek berpeluang besar melahirkan anak stunting (Amin, 2014).

Pendapatan keluarga pada peneltian ini tidak berhubungan dengan stunting. Keterbatasan ekonomi yaitu ketidakmampuan membeli bahan makanan yang berkualitas baik untuk memenuhi kebutuhan gizi keluarga. Anindita (2010) menyatakan tingkat ekonomi secara signifikan $(\mathrm{p}<0,05)$ berpengaruh terhadap stunting. Anak dari tingkat keluarga baik berpeluang memiliki balita tidak stunting 1,09 kali dibanding anak dengan keluarga dari tingkat ekonomi kurang/rendah. Kamal et al (2010) menyimpulkan stunting memiliki hubungan dengan pendapatan rendah pada keluarga.

\section{KESIMPULAN}

Terdapat hubungan antara pola menyusui, asupan energi, asupan karbohidrat, tinggi badan orang tua dengan stunting pada anak usia 6-24 bulan di Kabupaten Boyolali. Namun, tidak terdapat hubungan asupan lemak, protein, dan pendapatan keluarga dan stunting di Kabupaten Boyolali.

\section{SARAN}

Pemahaman terhadap orang tua tentang pentingnya air susu ibu, dan asupan anak balita hendaknya dapat ditingkatkan untuk mencegah terjadinya stunting.

\section{DAFTAR PUSTAKA}

Amin N A, Julia M. (2014). Faktor Sosiodemografi dan Tinggi Badan Orang Tua Serta Hubungannya dengan Kejadian Stunting pada balita usia 6-23 bulan. Jurnal Gizi dan Dietetik Indonesia. Yogyakarta: Universitas Gadjah Mada

Anindita, P. 2012. Hubungan Tingkat Pendidikan Ibu, Pendapatan Keluarga, Kecukupan Protein \& Zinc dengan Stunting pada Balita 6-35 Bulan di Kecamatan Tembalang Kota Semarang. Jurnal Kesehatan Masyarakat Vol 1, No 2

Arisman, 2009. Gizi dalam Daur Kehidupan. EGC, Jakarta.

Assis, et al. (2004). Childhood Stunting In Northeast Brazil : The Role of Schistosoma Mansoni Infection And Inadequate Dietary Intake. European Journal of Clinical Nutrition 58 : 1022-1029.

Bender, D. 2002. Introduction To Nutrition and Metabolism Third Edition. London: Taylor \& Francis eLibrary

Black, RE., Allen, LH., Bhutta, ZA., Caulfield, LE., De, Onis M., Ezzati, M. 2008. Maternal And Child Undernutrition: Global And Regional Exposures And Health Consequences. Lancet Journal. 2008;371:24360 .

Branca. F.. 2005. ..Encylopedia . of . Human Nutrition.Editor : Caballero, .B, Allen, L. \& Prentice, A. Elsivier Academic .Press..177 
Chunming, C. 2000. Fat Intake and Nutritional Status of Children in China. American Journal of Clinical Nutrition. 72(5)1368-1372.

Hutagalung, H., 2004. Karbohidrat. Bagian Ilmu Gizi Fakultas Kedokteran Universitas Sumatera Utara. http://library.usu.ac.id/download/fk/gizi-halomoan.pd

Hidayah, N. R. (2011). Faktor-Faktor Yang Berhubungan Dengan KejadianStunting Pada Balita Usia 24 - 59 Bulan Di Propinsi Nusa TenggaraTimur Tahun 2010 (Analisis Data Riskesdas 2010). Skripsi FakultasKesehatan Masyarakat, Program Sarjana Kesehatan Masyarakat, UI Depok.

Internasional Institute for Population Sciences, 2000. Childhood malnutrition: India

Jahari, AB dan Hadinsyah. (2012). Rata-Rata Berat Badan Orang Tua Dan Tinggi Badan Normal Orang Indonesia Menurut WHO 2007. Untuk Penyusunan Angka Kecukupan Gizi (AKG) 2012. Departemen Gizi Masyarakat FEMA IPB.

Meadow, R., Newell., S. 2005. Lecture Notes Pediatrika Edisi Ketujuh. Jakarta. Erlangga Medical Series.

Kamal, S.M.M., et al. 2010. Effects of wealth on nutritional status of pre-school children in Bangladesh. Mal. Nutr., 16.105-118

Kemenkes RI. 2010. Riset Kesehatan Dasar; RISKESDAS. Jakarta: Balitbang Kemenkes RI

Kemenkes RI. 2013. Riset Kesehatan Dasar; RISKESDAS. Jakarta: Balitbang Kemenkes RI

Koswara, S. 2006. Konsumsi Lemak yang Ideal Bagi Kesehatan. Ebook pangan. http://ebookpangan.com.

Kuchenbecker, J., Jordan, I., Reinbott, A., Herrmann, J., Jeremias, T., Kennedy, G., Muehlhoff, E., Mtimuni, B.,

Krawinkel, M.B. 2015. Exclusive breastfeeding and its effect on growth of Malawian infants: results from a cross-sectional study. Paediatr. Int. Child Health 35, 14-23.

Nasikhah R, Margawati A. (2012). Faktor Risiko Kejadian Stunting Pada Balita Usia 24 - 36 Bulan Di Kecamatan Semarang Timur. Journal of Nutrion College, vol 1, no 1, hal 176-184.

Rahayu LS. Associated of height of parents with changes of stunting status from 6-12 months to 3-4 years[Thesis]. Yogyakarta: Universitas Gajah Mada; 2011

Ramadhan,K F et al. Faktor-Faktor Yang Berhubungan Dengan Kejadian Stunting Pada Remaja Di Smp Setia Negara Depok.Nutri-Sains Journal Vol 2 No 1.1-8

Roesli, U. 2007. Mengenal ASI Eksklusif. Jakarta: PT. Pustaka Pembangunan Swadaya Nusantara

Sundari, Ermawati.2016.Hubungan Asupan Protein, Seng, Zat Besi, dan Riwayat Penyakit Infeksi dengan ZScore TB/U Pada Balita.Program Studi Ilmu Gizi Fakultas Kedokteran universitas Diponegoro Semarang

Sharlin, J., dan Edelstein, S. 2011. Essentials of Life Cycle Nutrition. Jones and Bartlett Publisher, LLC

Suhardjo. 2003. Perencanaan Pangan dan Gizi. Jakarta : Bumi Aksara.

Xiaoli, W., Beng, H., Sufang, G., Shusheng, L., Wenyuan, Z., Yan, W. 2009. Stunting And Overweight In The WHO Child Growth Standard: Malnutrition Among Children In Poor Area In China. Public Health Nutrition Journal: 12(11), 1991-1998 doi:10.1017/S1368980009990796 
Waterlow, J.C., \& Shetty, P.S. 2003. Adaption-Nutritional Aspects. Encylopedia of Food Science and Nutrition. Caballero, B, Trugo, L \& Finglas, P(Ed). Academic Press

WHO.2007.Growth

Reference

$5-19$

years

http://www.who.int/growthref/who2007_bmi_for_age/en/index.html

WHO, 2013. Childhood Stunting: Context, Causes and Consequences. WHO Conceptual framework.

WHO. 2013. Long-Term Effects Of Breastfeeding: A Systematic Review. Http://Www.Who.Int/Maternal_Child_Adolescent/Documents/Breastfeeding_Long_Term_Effects/En/ 